\title{
Hypolipidemic and Antioxidative Effects of African Star Apple Juice (Chrysophylum albidum) on Rats Fed on Diets High in Cholesterol and Oil
}

\author{
Modupe F. Bobadoye, Oluwaseun O. Bamisi, Victor N. Enujiugha* \\ Department of Food Science and Technology, Federal University of Technology, Akure, Nigeria \\ Email: *vnenujiugha@futa.edu.ng
}

Received 15 January 2015; accepted 20 August 2016; published 23 August 2016

Copyright (C) 2016 by authors and Scientific Research Publishing Inc.

This work is licensed under the Creative Commons Attribution International License (CC BY). http://creativecommons.org/licenses/by/4.0/

(c) (i) Open Access

\section{Abstract}

This study investigated the possible hypolipidemic and antioxidative effects of Chrysophyllum albidum juice in rats fed on highcholesterol and fatty diets (HFCD). The juice was expressed, pasteurized and frozen until needed. Diets were formulated by mixing at different ratios. Bio-assay of the blends was carried out for a period of 28 days. Twenty five male rats were divided into five groups of five each: a normal diet group, a high-cholesterol diet group, a high Fat/Cholesterol diet with 3 $\mathrm{ml}$ of African Star Apple Juice group, a high Fat/Cholesterol diet with $6 \mathrm{ml}$ of African Star Apple Juice group, and a high Fat/Cholesterol diet with $9 \mathrm{ml}$ of African Star Apple Juice group. Blood serum, selected tissues and organs were collected and the serum lipid profile, organ histology and oxidative stress test were carried out at the end of the animal experimentation. The levels of total cholesterol, triglyceride, low density lipoprotein-cholesterol, very low density lipoprotein-cholesterol and artherogenic index obtained from rats treated with African star apple juice $(3 \mathrm{ml}, 6 \mathrm{ml}$ and $9 \mathrm{ml}$ ) decreased significantly $(P \leq 0.05)$, compared respectively to the HFCD rats. The results also showed that treatment with African star apple (Chrysophyllum albidum) positively changed plasma antioxidant enzyme activities and lipid profiles in cholesterol-fed rats, and thus may have potential hypolipidemic and antioxidant effects, and by inference, the antiatherogenic properties in male rats. African star apple (Chrysophyllum albidum) juice could protect against oxidative stress linked atherosclerosis and decrease the atherogenic index, thereby supporting the local use of Chrysophyllum albidum in the management of atherosclerosis and hypertensive conditions.

\section{Keywords}

Chrysophyllum albidum, Atherosclerosis, Antioxidant Activity, Hypolipidemic Effects,

\footnotetext{
*Corresponding author.
}

How to cite this paper: Bobadoye, M.F., Bamisi, O.O. and Enujiugha, V.N. (2016) Hypolipidemic and Antioxidative Effects of African Star Apple Juice (Chrysophylum albidum) on Rats Fed on Diets High in Cholesterol and Oil. Food and Nutrition Sciences, 7, 825-843. http://dx.doi.org/10.4236/fns.2016.710083 


\section{Oxidative Stress}

\section{Introduction}

African star apple (Chrysophyllum albidum) fruit is a forest tree that belongs to the family Sapotaceae. Its natural occurrence has been reported in diverse ecozones in Nigeria, Uganda, Niger Republic, Cameroon and Cote d'Ivorie. The plant often grows to a height of $36.5 \mathrm{~m}$ though it may be smaller [1]. Its leaves are used in ethno-medicine [2]. The plant has in recent times become a crop of commercial value in Nigeria. The fleshy pulp of the fruits is eaten especially as snacks and relished by both young and old [3]. The fruit has been found to have the highest content of ascorbic acid with 1000 to $3330 \mu \mathrm{g}$ of ascorbic acid per $100 \mathrm{~g}$ of edible fruit or about 100 times that of oranges and 10 times that of guava or cashew [4]. Atherosclerotic disease causes over 19 million deaths annually, yet our understanding of the fundamental aspects of the genesis of the disease remains incomplete [5] [6]. Several studies have shown that an increased dietary intake of cholesterol results in hypercholesterolemia, which is known to eventually generate atherosclerosis and enhance the risk of coronary heart disease (CHD), fatty liver disease and cancer associated with hydroxyl radical formation [7]. The etiology of atherosclerosis appears to be a multi-factorial series of events, but the oxidation of lipoprotein is believed to be a primary event in the pathogenesis of atherosclerosis [8]. Thus, recent interest has been focused on strategies to enhance the removal of reactive oxygen species (ROS) by using antioxidants to enhance endogenous antioxidant responses. Natural antioxidants protect dietary lipids from oxidation, but may also provide health benefits associated with preventing damage due to biological degeneration. Antioxidative substances are believed to suppress the onset and development of atherosclerosis and reduce its progression. In addition, flavonoids and phenolic compounds have also been proved to have antioxidative effects. Thus, substances with both antioxidative and hypocholesterolemic properties are expected to be effective in preventing the formation and/or progression of atherosclerosis [9]. However, relatively less has been studied about the preventive effect of African star apple juice on atherosclerosis. This present study is therefore to evaluate the potentials of orally administered African star apple juice on the development of atherosclerosis by the evaluation of antioxidant enzyme response and lipid profiles in high-cholesterol-fed rats. However, little information about the detailed molecular mechanisms of cardio-protection of African star apple is available.

Based on available information, the detailed molecular mechanism on lipid-lowering effects of African star apple seems quite lacking and warrants further investigation. In addition, a high-fat dietary habit easily promotes production of malondialdehyde (MDA) and reactive oxygen species (ROS) in the body, thus enhancing the occurrence of atherosclerosis. African star apple contains polyphenols which are characterized as having antioxidative and anti-inflammatory capacities [10]. Hence, serum antioxidant capacity of African star apple juice on a high-fat/cholesterol diet also warrants a further scientific investigation.

The specific objectives of this study were to investigate changes of serum lipid profile in high-fat/cholesterol fed rats supplemented with African star apple juice, and determine oxidative status in high-fat/cholesterol fed rats supplemented with African star apple juice and assess the health implications of a high cholesterol diet.

\section{Materials and Methods}

\subsection{Sample Collection and Preparation}

African Star Apple was bought from a local market in Akure, Ondo state, Nigeria. The fruits were thoroughly cleaned by removing all foreign particles and the good ones were sorted out. The fruits were sliced and the seeds discarded while the pulp was scraped and milled using an attrition mill. The African star apple juice was then separated from the milled pulp via a muslin cloth. The juice extracted was then filled into sterilized glass bottles and thereafter, kept at refrigerated temperature for further use.

\subsection{Experimental Animals}

Twenty-five male Wistar albino rats weighing between $120 \mathrm{~g}$ and $150 \mathrm{~g}$ were obtained from a private rats weaning outfit near the University of Ibadan, Oyo State, Nigeria. The rats were maintained in accordance with 
internationally accepted ethical guidelines for the care of laboratory animals. Experimental rats were acclimatized by access to food and water ad libitum for 1 week. They were then randomly assigned to five groups and housed in netted wooden cages at room temperature $25^{\circ} \mathrm{C} \pm 2^{\circ} \mathrm{C}$ for an experimental period of twenty-eight days and fed with high cholesterol diet prepared using $1 \% \mathrm{w} / \mathrm{v}$ cholesterol except the control group.

\subsection{Experimental Design}

Age-matched Albino rats weighing $130 \pm 20$ grams were divided into five groups (A-E) of five animals per group. The animals were housed into the cage cells.

Group A: Animals in this group received basal diet (normal diet) i.e. Low Fat/Cholesterol Diet throughout the duration of the experiment and served as untreated control.

Group B: Animals consumed High Fat/Cholesterol Diet and water ad libitum throughout the duration of the experiment and served as treated control.

Groups C: Animals consumed High Fat/Cholesterol Diet and water ad libitum and recieved oral adminstration of $3 \mathrm{ml}$ of African Star Apple Juice.

Group D: Animals in this group consumed High Fat/Cholesterol Diet and water ad libitum and recieved oral adminstration of $6 \mathrm{ml}$ of African Star Apple Juice.

Group E: Animals in this group consumed High Fat/Cholesterol Diet and water ad libitum and recieved oral adminstration of $9 \mathrm{ml}$ of African Star Apple Juice.

\subsection{Diet Formulation}

The experimental diets were prepared by modifying the standard methods described by [10]. The compositions of the diets were as shown in Table 1. After a thorough homogenization of the ingredients, the mixture was baked in an oven at a temperature of about $110^{\circ} \mathrm{C}$ for $60 \mathrm{~min}$.

\subsection{Organ Separation}

All animals in the present study were sacrificed using anesthesia. The target organs (heart, liver and kidney) were excised using scissors and forceps.

\subsection{Preparation of Serum}

Rats were dissected and blood collected through cardiac puncture into sterilizedvials and ejected into clean centrifuge tubes and allowed to stand for one hour. Serum was prepared by centrifugation at $3000 \times \mathrm{g}$ for 15 minutes at $25^{\circ} \mathrm{C}$. The clear supernatant was used for the serum lipid profile analysis.

Table 1. Composition of experimental diets.

\begin{tabular}{cccccc}
\hline & & \multicolumn{3}{c}{ Diet groups } \\
\hline Ingredients & A & B & C & D & E \\
\hline Casein (mg) & 100 & 100 & 100 & 100 & 100 \\
Oil (ml) & 5 & 10 & 10 & 10 & 10 \\
Wheat flour (g) & 60 & 60 & 60 & 60 & 50 \\
Vitamin/mineral mix (mg) & 50 & 50 & 50 & 45 & 40 \\
Water (ml) & 45 & 45 & 1 & 1 & 1 \\
Cholesterol (\% wt) & - & 1 & 3 & 6 \\
\hline
\end{tabular}

A = Low Fat Cholesterol Diet (LFCD), B = High Fat/Cholesterol Diet (HFCD), C = High Fat/Cholesterol Diet 3 ml African Star Apple Juice $(\mathrm{HFCD} / 3), \mathrm{D}=$ High Fat/Cholesterol Diet+ $6 \mathrm{ml}$ African Star Apple Juice (HFCD/6), E = High Fat/Cholesterol Diet+ $9 \mathrm{ml}$ African Star Apple Juice (HFCD/9). 


\subsection{Preparation of Post-Mitochondrial Fraction (PMF)}

The liver tissues were rinsed in ice cold $1.15 \%$ potassium chloride solution, blotted with filter paper, and weighed. They were chopped into bits and homogenized in ten volumes of homogenizing buffer ( $\mathrm{pH} 7.4$ ) using a potter-elvegin homogenizer. The resulting homogenate was centrifuged at $10,000 \times \mathrm{g}, 4^{\circ} \mathrm{C}$ for 10 minutes to obtain the post mitochondrial fraction. The supernatant was collected, stored under $4^{\circ} \mathrm{C}$ and then used for biochemical analysis.

The clear supernatant was used to evaluate the levels of lipid peroxidation (LPO), and reduced glutathione (GSH), and activities of superoxide dismutase (SOD) and catalase (CAT).

\subsection{Determination of Phytochemicals in African Star Apple Juice}

\subsubsection{Test for Flavonoid}

Five milliliters $(5 \mathrm{ml})$ of dilute ammonia solution was added to $2 \mathrm{ml}$ of the extract. This was followed by the addition of $2 \mathrm{ml}$ concentrated $\mathrm{H}_{2} \mathrm{SO}_{4}$. A yellow coloration was observed and the yellow colouration disappeared on standing [11].

\subsubsection{Test for Saponin}

The ability of saponins to produce frothing in aqueous solution was used as screening test for the compound. Exactly $1 \mathrm{ml}$ of the extract was shaken with $2 \mathrm{ml}$ distilled water in a test tube, and subsequent sign/manifestation of frothing was carefully observed [12].

\subsubsection{Test for Tannin}

Five milliliters of the extract was stirred with $5 \mathrm{ml}$ distilled water, and the mixture was filtered. The filtrate was treated with ferric chloride, and the prescence of a black-green precipitate showed the presense of tannins [13].

\subsubsection{Test for Phlobatannin}

Five milliliters of the extract was boiled with $5 \%$ aqueous $\mathrm{HCl}$. The absence of a red precipitate indicated the absence of phlobatannins [13].

\subsubsection{Test for Alkaloid}

Five grammes of the powdered sample were weighed into $250 \mathrm{ml}$ beaker. Then $100 \mathrm{ml}$ of $10 \%$ acetic acid in ethanol was added. The mixture was covered and allowed to stand for $4 \mathrm{~h}$. This was then filtered and the extract concentrated on a water bath to $1 / 4$ of the original volume. Thereafter, concentrated ammonium hydroxide added drop wise until precipitation was completed. The solution was then allowed to settle and the precipitate collected, washed with diluted ammonium hydroxide and filtered. The residue that was dried and weighed was alkaloid [14].

\subsubsection{Test for Steroid}

Two milliliters of acetic acid was added to $0.5 \mathrm{ml}$ of the extract. Two milliliters of concentrated $\mathrm{H}_{2} \mathrm{SO}_{4}$ was thereafter added. The prescence of a violet to blue colour indicated the prescence of steroids [14].

\subsubsection{Test for Terpenoid}

Five milliliters of the extract was mixed with $2 \mathrm{ml}$ chloroform. Three milliliters of concentrated $\mathrm{H}_{2} \mathrm{SO}_{4}$ was carefully added to the solution to form a thin layer. The absence of a reddish brown coloration at the interface gave a negative result for terpenoids [14].

\subsubsection{Test for Cardiac Glycoside-Salkowski Test}

A small amount of the extract was hydrolysed in $2 \mathrm{ml}$ of HCL solution and neutralized with equal amount of sodiun hydroxide solution. Few drops of fehling's solution was added. Red precipitates indicated the presence of glycosides [15].

\subsubsection{Test for Volatile Oil}

The extract was dissolved in $90 \%$ alcohol and drops of ferric chloride were added. Green colouration, indicate 
the presence of volatile oils [14].

\subsection{Determination of Antioxidant Composition}

\subsubsection{Determination of Vitamin C Content}

Vitamin $\mathrm{C}$ content of the African star apple juice was determined using the method of Benderitta et al. [15]. Briefly, $75 \mu \mathrm{l} \mathrm{DNPH} \mathrm{(2} \mathrm{g} \mathrm{dinitro-phenyl} \mathrm{hydrazine,} 230 \mathrm{mg}$ thiourea and $270 \mathrm{mg} \mathrm{CuSO}{ }_{4} \cdot 5 \mathrm{H}_{2} \mathrm{O}$ in $100 \mathrm{ml}$ of 5 mol $\left.\cdot 1^{-1} \mathrm{H}_{2} \mathrm{SO}_{4}\right)$ was added to $200 \mu 1$ reaction mixture $(300 \mu \mathrm{l}$ of an appropriate dilution of the polar extract with $100 \mu 113.3 \%$ (TCA) and water). The reaction mixtures were subsequently incubated for 3 hours at $37^{\circ} \mathrm{C}$, then $0.5 \mathrm{ml}$ of $65 \% \mathrm{H}_{2} \mathrm{SO}_{4}(\mathrm{v} / \mathrm{v})$ was added to the medium, their absorbance was measured at $520 \mathrm{~nm}$ and the vitamin $\mathrm{C}$ content of the juice was subsequently calculated.

\subsubsection{Determination of Total Phenol Content}

The total phenol content of the African star apple juice was determined using the method reported by [16]. Appropriate dilutions of the juice was oxidized with $2.5 \mathrm{ml}$ of $10 \%$ Folin-Ciocalteau's reagent $(\mathrm{v} / \mathrm{v})$ and neutralized by $2.0 \mathrm{ml}$ of $7.5 \%$ sodium carbonate. The reaction mixture was incubated for 40 minutes at $45^{\circ} \mathrm{C}$ and the absorbance was measured at $765 \mathrm{~nm}$ in the spectrophotometer. The total phenol content was subsequently calculated using gallic acid as standard.

\subsubsection{Determination of Total Flavonoid Content}

The total flavonoid content of African star apple juice was determined using a slightly modified method reported by Meda et al. [17]. Briefly, $0.5 \mathrm{ml}$ of appropriately diluted sample was mixed with $0.5 \mathrm{ml}$ methanol, $50 \mu 1$ of $10 \% \mathrm{AICI}_{3}, 50 \mu \mathrm{l}$ of $1 \mathrm{~mol}^{-1}{ }^{-1}$ potassium acetate and $1.4 \mathrm{ml}$ water and allowed to incubate at room temperature for 30 minutes. Thereafter, the absorbance of the reaction mixture was subsequently measured at $415 \mathrm{~nm}$. The total flavonoid was calculated using quercetin as standard.

\subsubsection{DPPH Free Radical Scavenging Ability}

The free radical scavenging ability of the African star apple juice against DPPH (1,1-diphenyl-2 picrylhydrazyl) free radical was evaluated as described by Gyamfi et al. [18]. Briefly, an appropriate dilution of the juice (1 ml) was mixed with $1 \mathrm{ml}$ of $0.4 \mathrm{mmol} \cdot 1^{-1}$ methanolic solution containing DPPH radicals. The mixture was left in the dark for 30 minutes and the absorbance was measured at $516 \mathrm{~nm}$. The DPPH free radical scavenging ability was subsequently calculated with respect to the reference (which contains all the reagents without the test sample).

\subsubsection{Determination of Reducing Property}

The reducing property of the African star apple juice was determined by assessing the ability of the extract to reduce ferric chloridesolution as described by Oyaizu [19]. A $2.5 \mathrm{ml}$ aliquot was mixed with $2.5 \mathrm{ml}$ of 200 mmol $\cdot 1^{-1}$ sodium phosphate buffer $(\mathrm{pH} 6.6)$ and $2.5 \mathrm{ml}$ of $1 \%$ potassium ferricyanide. The mixture was incubated at $50^{\circ} \mathrm{C}$ for 20 minutes and then $2.5 \mathrm{ml}$ of $10 \%$ trichloroacetic acid was added. This mixture was centrifuged at $650 \times \mathrm{g}$ for 10 minutes. $5 \mathrm{ml}$ of the supernatant was mixed with an equal volume of water and $1 \mathrm{ml}$ of $0.1 \%$ ferric chloride. The absorbance was measured at $700 \mathrm{~nm}$. The ferric reducing antioxidant property was subsequently calculated using ascorbic acid as standard.

\subsection{6. $\mathrm{Fe}^{2+}$ Chelation Assay}

The $\mathrm{Fe}^{2+}$ chelating ability of the African star apple juice was determined using a modified method of Minotti and Aust [20] with slight modification by [21]. Freshly prepared $500 \mu \mathrm{mol} \cdot 1^{-1} \mathrm{FeSO}_{4}(150 \mu \mathrm{l})$ was added to a reaction mixture containing $168 \mu \mathrm{l}$ of $0.1 \mathrm{~mol} \cdot 1^{-1}$ Tris-HCL (pH 7.4), $218 \mu \mathrm{l}$ saline and the juice $(0-25 \mu \mathrm{l})$. The reaction mixture was incubated for 5 minutes, before the addition of $13 \mu 1$ of $0.25 \% 1,10$-phenanthroline (w/v). The absorbance was subsequently measured at $510 \mathrm{~nm}$ in a spectrophotometer. The $\mathrm{Fe}^{2+}$ chelating ability was subsequently calculated with respect to the reference (which contains all the reagents without the test sample).

\subsection{Serum Lipid Profile Determination}

Chemicals: Kit reagents for total cholesterol, triglycerides and high density lipoprotein cholesterol were obtained from a chemical store in Idumota, Lagos State, Nigeria. Dissecting tools and anaesthesia (trichlorome- 
thane) were obtained from the Biochemistry Laboratory, Science Technology Department, Federal Polytechnic, Ado-Ekiti, Nigeria.

Sample Collection: The animals were starved overnight for 12 hours before the blood was collected. Rats were anaesthetized with cotton wool treated with trichloromethane $\left(\mathrm{CHCl}_{3}\right)$ and venous blood samples were collected by direct heart puncture in sterilized vials and ejected into EDTA bottles. The blood samples were centrifuged at $4000 \mathrm{rpm}$ for 10 minutes at $25^{\circ} \mathrm{C}$ and serum was recovered.

Serum Lipid Assessment: The levels of serum Total Cholesterol (TC), High Density Lipoprotein-Cholesterol (HDL-C) and Triglycerides (TG) measurement were performed at the Food Chemistry Laboratory, Food Technology Department, Federal Polytechnic, Ado-Ekiti according to GPO-PAD method, CHOD-PAP and Enzymatic end point methods respectively i.e. the manufacturer's procedures in the kit reagents. Low density Lipoprotein (LDL-C) was calculated according to the methods of [22]. The atherogenic index (AI) was calculated as $\mathrm{AI}=(\mathrm{TC}-\mathrm{HDL}) / \mathrm{HDL}$.

\subsubsection{Determination of Total Cholesterol}

Reagent blank and standard were prepared by mixing $10 \mu \mathrm{l}$ distilled water and $10 \mu \mathrm{l}$ standard respectively each with $1000 \mu \mathrm{l}$ of reagent. The three aliquots were separately mixed, incubated for 10 minutes at $25^{\circ} \mathrm{C}$. The absorbance of the samples $\left(\mathrm{A}_{\text {sample }}\right)$ against the reagent blank was measured within 60 minutes at $500 \mathrm{~nm}$-wavelength.

$$
\text { Conc of cholesterol in samples }=553 \times \Delta \mathrm{A}(\mathrm{mg} / \mathrm{dl})
$$

\subsubsection{Determination of HDL-Cholesterol}

Precipitation: About $500 \mu \mathrm{l}$ of sample and standard each was separately mixed with precipitant. The mixtures were allowed to sit for 10 minutes at room temperature and then centrifuged for 10 minutes at $4000 \mathrm{rpm}$. The clear supernatant was separated off within two hours and the cholesterol content was determined by the CHODPAP methods i.e. $100 \mu \mathrm{l}$ each of reagent blank, standard and sample were separately mixed with $1000 \mu \mathrm{l}$ of reagent. The three aliquots were incubated for 10 minutes at $25^{\circ} \mathrm{C}$. The absorbance of the sample $\left(\mathrm{A}_{\text {sample }}\right)$ and standard $\left(\mathrm{A}_{\text {standard }}\right)$ were measured against the reagent blank within 60 minutes at $500 \mathrm{~nm}$ wavelength.

$$
\text { HDL-C }=180 \times \Delta \text { A samples }(\mathrm{mg} / \mathrm{dl})
$$

\subsubsection{Determination of Triglycerides}

Ten microliter $(10 \mu \mathrm{l})$ each of standard and sample were separately mixed with $1000 \mu \mathrm{l}$ of reagent. The mixtures were incubated for 10 minutes at $25^{\circ} \mathrm{C}$. The absorbance of the sample $\left(\mathrm{A}_{\text {sample }}\right)$ and standard $\left(\mathrm{A}_{\text {standard }}\right)$ were measured against the reagent blank within 60 minutes at $500 \mathrm{~nm}$ wavelength

$$
\text { Triglyceride concentration }=\mathrm{A}_{\text {sample }} \times 1048 \mathrm{mg} / \mathrm{dl}
$$

\subsubsection{Determination of LDL-Cholesterol}

The Low Density Lipoprotein-Cholesterol was calculated according to the method of Friedworld et al. [23].

$$
\text { LDL-Cholesterol }=\text { Total cholesterol }- \text { Triglycerides }- \text { HDL-Cholesterol }
$$

\subsubsection{Determination of Atherogenic Index (AI)}

The atherogenic index (AI), which is calculated using following formula, is a marker of plasma atherogenicity because it is increased in people with higher risk of cardiovascular diseases. The atherogenic index (AI) was calculated as $\mathrm{AI}=(\mathrm{TC}-\mathrm{HDL}) / \mathrm{HDL}$.

\subsection{Biochemical Analysis}

\subsubsection{Determination of Catalase Activity of Samples}

This experiment was carried out using the method described by Sinha [24].

1) Procedure

One mililiter of sample was mixed with $9 \mathrm{ml}$ distilled $\mathrm{H}_{2} \mathrm{O}$ to give 1 in 10 dilution of the sample. The assay mixture contained $4 \mathrm{ml}$ of $\mathrm{H}_{2} \mathrm{O}_{2}$ solution $(800 \mu$ moles) and $5 \mathrm{ml}$ of phosphate buffer in a $10 \mathrm{ml}$ flat bottom flask. 
Properly diluted enzyme preparation $(1 \mathrm{ml})$ was rapidly mixed with the reaction mixture by a gentle swirling motion. The reaction was run at room temperature. A $1 \mathrm{ml}$ portion of the reaction mixture was withdrawn and blown into $2 \mathrm{ml}$ dichromate/acetic acid reagent at 60 seconds intervals. The hydrogen peroxide contents of the withdrawn sample were determined by the method described above.

2) Calculation

Catalase activity, $\mathrm{K}$ was calculated using the relation below:

$$
\text { catalaseactivity, } \mathrm{K}=\frac{\mathrm{H}_{2} \mathrm{O}_{2} \text { consumed }}{\text { Mgprotein }}
$$

where, $\mathrm{H}_{2} \mathrm{O}_{2}$ consumed $=800-\mathrm{H}_{2} \mathrm{O}_{2}$ concentration remaining.

$\mathrm{H}_{2} \mathrm{O}_{2}$ concentration remaining is extrapolated from the standard curve for catalase activity.

\subsubsection{Determination of Superoxide Dismutase (SOD) Activity}

The level of SOD activity was determined by the method of Misra and Fridovich [25].

1) Procedure

One milliliter of sample was diluted in $9 \mathrm{ml}$ of distilled water to make a 1 in 10 dilution. An aliquot of the diluted sample was added to $2.5 \mathrm{ml}$ of $0.05 \mathrm{M}$ carbonate buffer ( $\mathrm{pH}$ 10.2) to equilibrate in the spectrophotometer and the reaction started by the addition of $0.3 \mathrm{ml}$ of freshly prepared $0.3 \mathrm{mM}$ adrenaline to the mixture which was quickly mixed by inversion. The reference cuvette contained $2.5 \mathrm{ml}$ buffer, $0.3 \mathrm{ml}$ of substrate (adrenaline) and $0.2 \mathrm{ml}$ of water. The increase in absorbance at $480 \mathrm{~nm}$ was monitored every 30 seconds for 150 seconds.

2) Calculation

$$
\frac{\text { Increase in absorbance per minute }}{2.5}=\mathrm{A}_{3}-\mathrm{A}_{0}
$$

where $\mathrm{A}_{0}=$ absorbance after seconds; $\mathrm{A}_{3}=$ absorbance 150 seconds

$$
\% \text { inhibition }=\frac{100-\text { increase in absorbance for substrate }}{\text { Increase in absorbance of bland }} \times 100
$$

One unit of SOD activity was given as the amount of SOD necessary to cause $50 \%$ inhibition of the oxidation of adrenaline to adrenochrome during 1 minute.

\subsubsection{Estimation of Reduced Glutathione (GSH) Level}

The method of Bentler [26] was followed in estimating the level of reduced glutathione (GSH).

1) Procedure

The sample, of which $0.2 \mathrm{ml}$ was added to $1.8 \mathrm{ml}$ of distilled water and $3 \mathrm{ml}$ of the precipitating solution was mixed with sample. The rate of addition was not critical. The mixture was then allowed to stand for approximately 5 minutes and then filtered. At the end of the fifth minute, $1 \mathrm{ml}$ of filtrate was added of $4 \mathrm{ml}$ of $0.1 \mathrm{M}$ phosphate buffer. Finally $0.5 \mathrm{ml}$ of the Ellman reagent was added.

A blank was prepared with $4 \mathrm{ml}$ of the $0.1 \mathrm{M}$ phosphate buffer, $1 \mathrm{ml}$ of the diluted precipitating solution (3 parts to 2 parts of distilled water) and $0.5 \mathrm{ml}$ of the Ellman reagent. The optical density was measured at 412 $\mathrm{nm}$. GSH was proportional to the absorbance at that wavelength and the estimate was obtained from the GSH standard.

\subsubsection{Assessment of Lipid Peroxidation}

Lipid peroxidation was determined by measuring the formation of thiobarbituric acid reactive substances (TBARS) according to the method of Vershrey and Kale [27].

1) Procedure

An aliquot of $0.4 \mathrm{ml}$ of the liver PMF was mixed with $1.6 \mathrm{ml}$ of Tris- $\mathrm{KCl}$ buffer to which $0.5 \mathrm{ml}$ of $30 \%$ TCA was added. Then $0.5 \mathrm{ml}$ of $0.75 \%$ TBA was added and placed in a water bath for 45 minutes at $80^{\circ} \mathrm{C}$. This was then cooled in ice and centrifuged at $3000 \times \mathrm{g}$. The clear supernatant was collected and absorbance measured against a reference blank of distilled water at $532 \mathrm{~nm}$. The MDA level was calculated according to the method of Adam and Seregi [28]. Lipid peroxidation in units/mg protein or gram tissue was computed with a molar extinction coefficient of $1.56 \times 10^{5} \mathrm{M}^{-1} \cdot \mathrm{Cm}^{-1}$. 
2) Calculation

$$
\operatorname{MDA}(\text { units } / \mathrm{mg} \text { protein })=\frac{\text { Absorbance } \times \text { Volume of mixture }}{\text { E532nm } \times \text { Volume of sample } \times \text { mg protein }}
$$

\subsection{Histological Examination of Experimental Animals' Organs}

Histopathological assay of the organs (heart and liver) excised from the rats in the different diet groups (A, B, C, $\mathrm{D}$ and $\mathrm{E}$ ), was determined by reading the photomicrographs obtained from the slides prepared from the organs by a Pathologist at the Veterinary Anatomy Department, University of Ibadan, Nigeria using the standard methods described by Bancroft and Steven [29].

Procedure: The tissues pieces were fixed in a suitable fixator, typically formalin and embedded in melted paraffin wax. The wax block was then cut on a microtome to yield a thin slice of paraffin containing the tissue. The specimen slice was then applied to a microscope slide, air dried and heated to cause the specimen to adhere to the glass slide. Residual paraffin was then dissolved and rinsed with an acid-alcohol followed by rinsing with water to remove the acid alcohol. The hematoxylin was blued by the bluing solution. The bluing solution was removed by rinsing with water. Other cytoplasmic elements were stained with an alcoholic solution of eosin $\mathrm{Y}$, a red stain and a light green. The excess stain was removed by water in series of sequential washes in a dehydrating reagent. The slide was contacted with a chemical clearing agent (toluene, xylene or t-butanol) to remove residual dehydrating reagent remaining from the washing step. A cover slip mountant was applied to the slide after removing the slide from a chemical clearing agent. The clearing agent evaporates and the mountant hardens leaving a stained and mounted slide. Histopathological assessment and photomicrography of the prepared slides was done by a pathologist using an Olympus light microscope with attached Kodak digital camera.

\subsection{Statistical Analysis}

All analyses were carried out in triplicate and data were subjected to Analysis of Variance (ANOVA) using Statistical Package for Social Sciences (SPSS) version 15.0 (for windows). Statistical differences between mean values were determined by Duncan's Multiple Range Tests and accepted at $\mathrm{P}<0.05$.

\section{Results and Discussion}

\subsection{Phytochemical Screening}

Table 1 shows the results of the phytochemical screening of Chrysophyllum albidum juice. The phytochemical screening of Chrysophyllum albidum juice revealed the presence of steroids, tannins, alkaloids, flavonoids, cardiac glucoside, saponins and volatile oil while there was absence of phlobatannins and terpenoids.

\subsection{Antioxidant Indices}

The results for the evaluation of antioxidant properties of African Star Apple juice as assessed by sixin vitro methods (Vitamin C, Flavonoid, Phenol, DPPH, ferric reducing antioxidant property and Iron (II) chelating ability)are shown in Table 2.

Table 2. Antioxidant indices of Chrysophyllum albidum.

\begin{tabular}{cc}
\hline Compound & Contents \\
\hline Vitamin C (mg/100ml) & $3090 \pm 0.62$ \\
Flavonoid (mg/100ml) & $174 \pm 0.32$ \\
Phenol (mg/100ml) & $25 \pm 0.48$ \\
DPPH (\%) & $91.35 \pm 0.33$ \\
Reducing Property (mg/100ml) & $125 \pm 0.15$ \\
Iron Chelation (\%) & $18.77 \pm 0.59$ \\
\hline
\end{tabular}

Values in the table are expressed as mean $\pm \operatorname{SEM}(n=5)$. 


\subsection{Serum Lipid Profile of Albino Rats after 4-Week Consumption of Experimental C. albidum Diets}

The results of the serum lipid profile (in vivo) are shown in Table 3. The values obtained for each of the parameters did not exceed the safe limits of US guidelines for serum lipid profile. Highest blood cholesterol level was recorded for the animals that fed on High Fat/Cholesterol diets. Since the elevation of serum cholesterol, triglycerides and $\beta$-lipoprotein are of health significance, $\mathrm{HFCD} / 9$ would be better for consumption.

\subsection{Biochemical Analysis}

The results of the biochemical analysis are shown in Figures 1-4. The liver was assayed for Catalase, Superoxide Dismutase, Reduced Glutathione and Lipid Peroxidation. The result obtained showed that ASAJ inhibited

Table 3. Serum lipid profile of albino rats after 4 week consumption of experimental C. albidum diets (mg/dl).

\begin{tabular}{ccccccc}
\hline Parameters & LFCD & HFCD & HFCD/3 & HFCD/6 & HFCD/9 & US guideline \\
\hline Cholesterol & $109.81 \pm 0.00^{\mathrm{d}}$ & $215.67 \pm 3.19^{\mathrm{a}}$ & $182.77 \pm 9.57^{\mathrm{b}}$ & $165.90 \pm 5.53^{\mathrm{c}}$ & $169.74 \pm 3.19^{\mathrm{c}}$ & $<240$ \\
Triglyceride & $91.45 \pm 0.00^{\mathrm{e}}$ & $187.48 \pm 4.28^{\mathrm{a}}$ & $148.32 \pm 0.00^{\mathrm{b}}$ & $128.15 \pm 4.29^{\mathrm{c}}$ & $122.47 \pm 4.29^{\mathrm{d}}$ & $<200$ \\
HDL-C & $46.40 \pm 2.97^{\mathrm{a}}$ & $20.10 \pm 1.21^{\mathrm{d}}$ & $35.9 \pm 4.20^{\mathrm{b}}$ & $26.40 \pm 2.43^{\mathrm{c}}$ & $39.4 \pm 3.21^{\mathrm{b}}$ & $\geq 10$ \\
LDL-C & $45.12 \pm 2.97^{\mathrm{d}}$ & $158.07 \pm 3.50^{\mathrm{a}}$ & $117.21 \pm 5.40^{\mathrm{c}}$ & $113.87 \pm 6.48^{\mathrm{b}}$ & $105.85 \pm 6.98^{\mathrm{b}}$ & $<160$ \\
VLDL-C & $18.33 \pm 0.00^{\mathrm{e}}$ & $37.65 \pm 0.86^{\mathrm{a}}$ & $29.72 \pm 0.00^{\mathrm{b}}$ & $25.76 \pm 0.86^{\mathrm{c}}$ & $24.27 \pm 0.86^{\mathrm{d}}$ & \\
AI & $0.93 \pm 0.13^{\mathrm{e}}$ & $7.61 \pm 0.50^{\mathrm{a}}$ & $4.09 \pm 0.29^{\mathrm{d}}$ & $5.28 \pm 0.62^{\mathrm{b}}$ & $3.31 \pm 0.35^{\mathrm{c}}$ &
\end{tabular}

Values in the table are expressed as mean \pm SD for five Animals. Means in the same row with different superscripts are significantly different $(\mathrm{P}<$ $0.05)$.

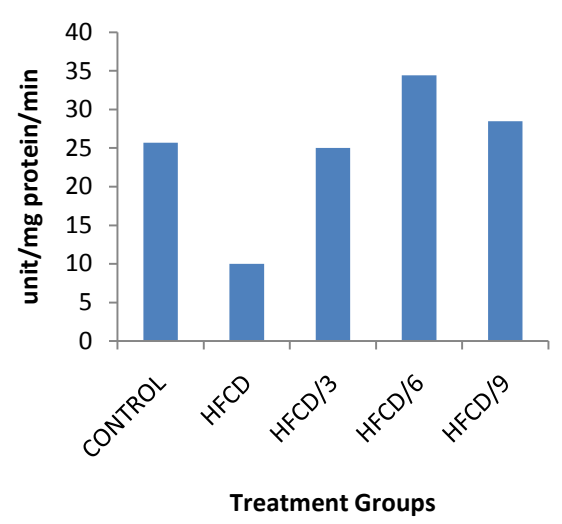

Figure 1. Effect of Chrysophyllum albidum on liver catalase level of rats fed High fat/Cholesterol diet.

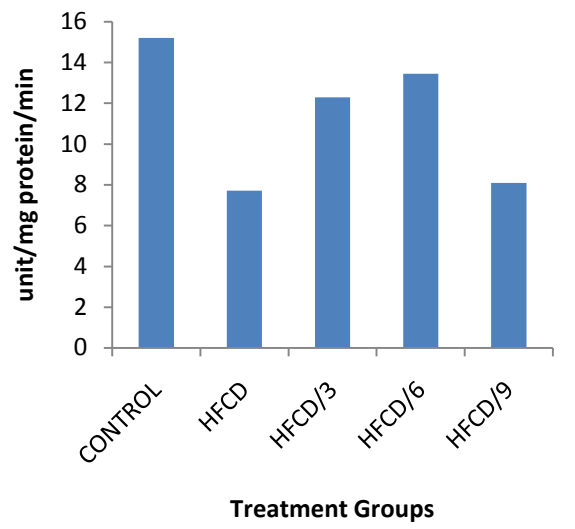

Figure 2. Effect of Chrysophyllum albidum on liver superoxide dismutase level of rats fed high fat/Cholesterol diet. 


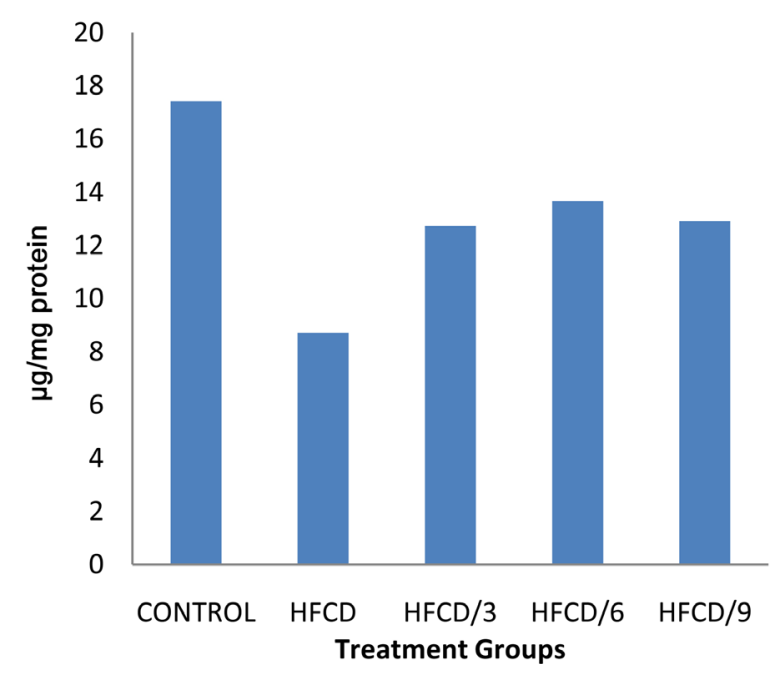

Figure 3. Effect of Chrysophyllum albidum on liver glutathione level of rats fed High fat/Cholesterol diet.

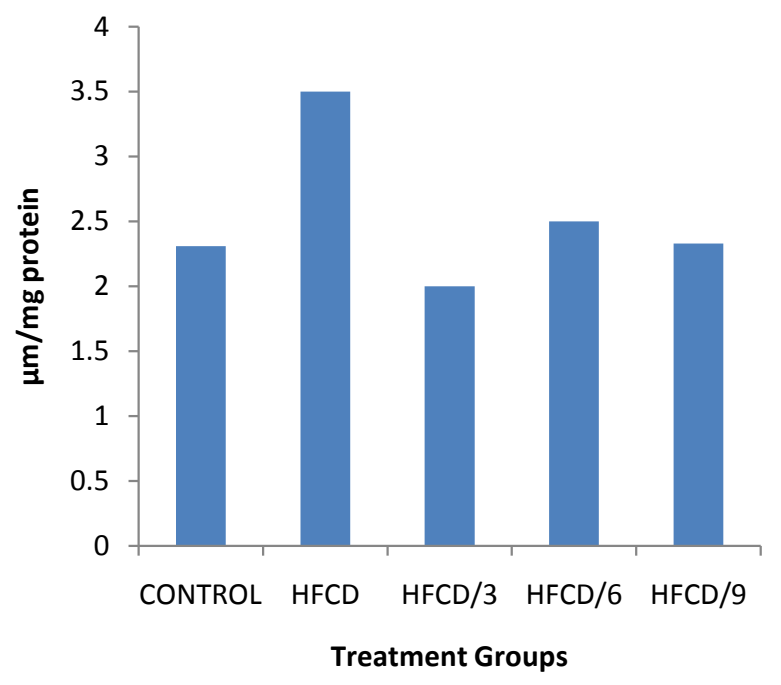

Figure 4. Quantification of extent of lipid peroxidation in winstar rat livers.

HFCD decrease in catalase, superoxide Dismutase and Reduced Gluthatione activities and HFCD increase in MDA level.

\subsection{Organs Histology}

The results of histological examination of the organs excised from the albino rats that fed on experimental C. albidum diets over a four-week period are shown in Figure 5 and Figure 6. The summary of the conclusions drawn from the photomicrographs are shown in Table 4 . The photomicrographs were magnified $(\times 400)$ to show the conditions of the cell vacuoles and hepatocytes. Low Fat/Cholesterol diets gave the safest results.

The results in Table 5 show the phytochemical analysis of the C. albidum juice was found to contain saponins, alkaloids, cardiac glycosides ,tannins, flavonoids, steroids and volatile oil, while it showed absence of phlobatannins and terpenoids.

\subsection{Phytochemicals}

African star apple juice showed the presence of steroids, tannins, alkaloids, flavonoids, cardiac glycoside, 


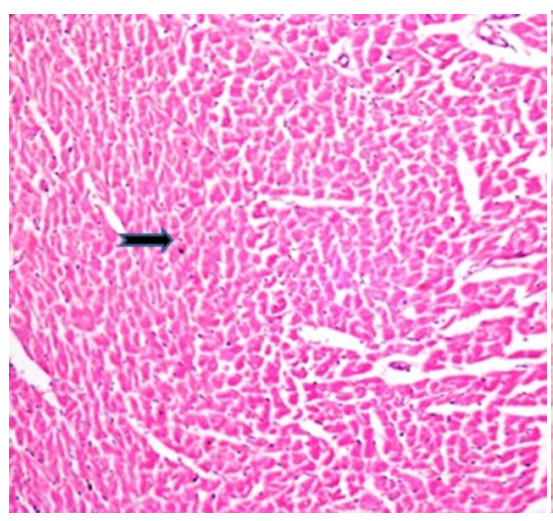

(a)

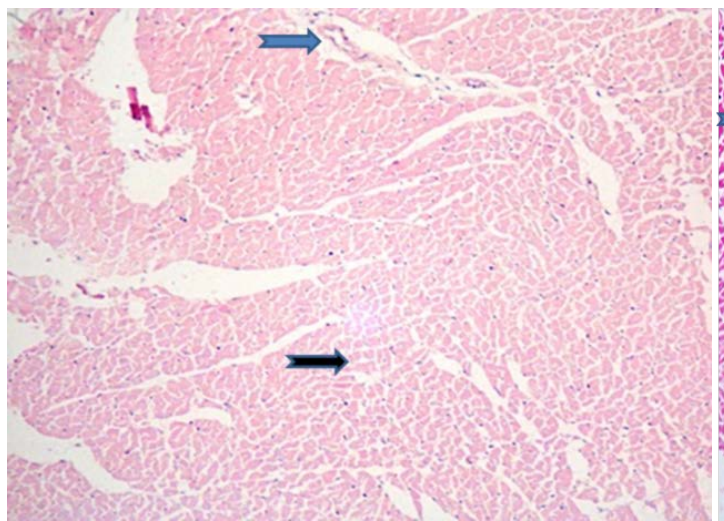

(c)

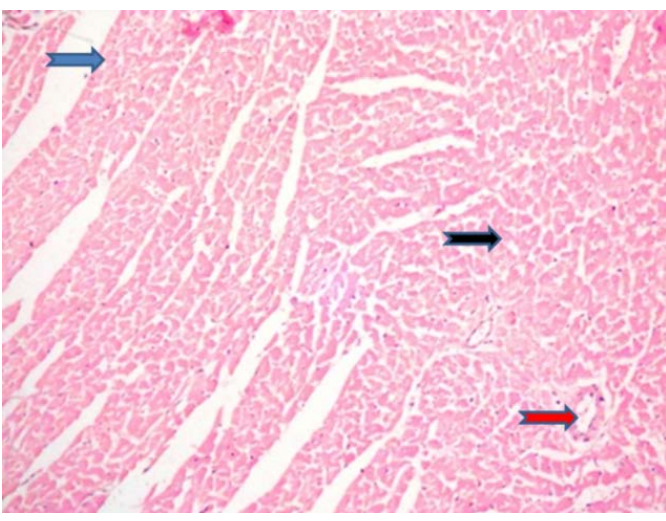

(b)

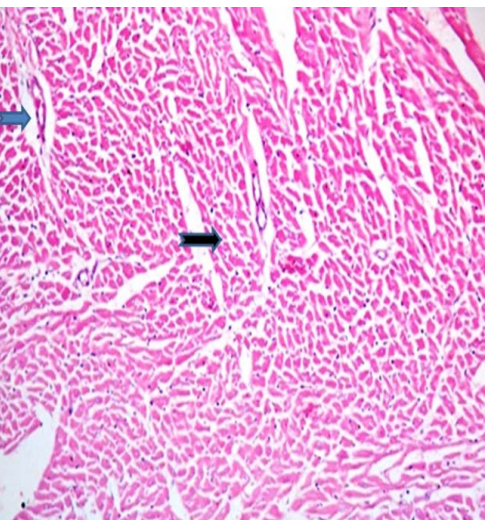

(d)

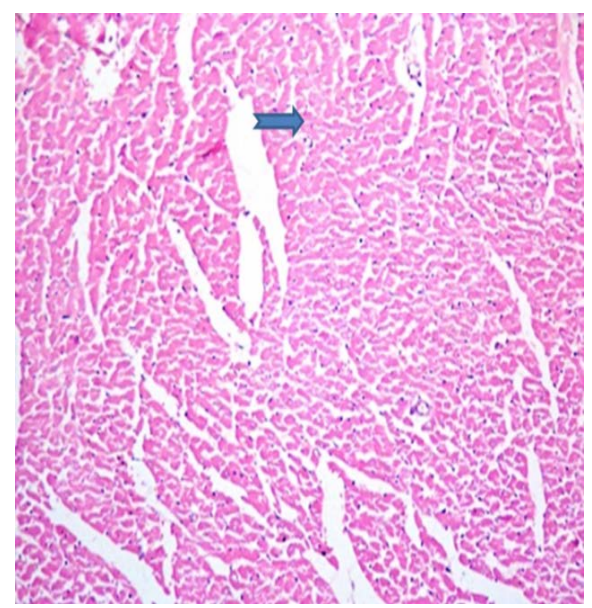

(e)

Figure 5. Histological Examination of Heart (photomicrographs) $(\times 400$ mag. $)(a)=$ LFCD, $(b)=$ $\mathrm{HFCD},(\mathrm{c})=\mathrm{HFCD} / 3,(\mathrm{~d})=\mathrm{HFCD} / 6,(\mathrm{e})=\mathrm{HFCD} / 9$.

saponins and volatile oil. The presence of these phytochemicals in African star apple juice is suggestive of its potent bioactivity. Specifically, saponin is known to elicit serum cholesterol lowering activity by causing resinlike action, thereby reducing the enterohepatic circulation of bile acids [30]. Presence of tannins suggests the ability of this plant to play a major role as anti-diarrhoeic and anti-haemorrhagic agent [31]. The cardiac glycosides have been used for over two centuries as stimulants in the case of cardiac failure [15].

Plants are enriched with bioactive phytochemicals that might be effective therapy, safe and cheap. The phytochemical analysis of Chrysophylum albidum juice showed the presence of secondary metabolite such as 


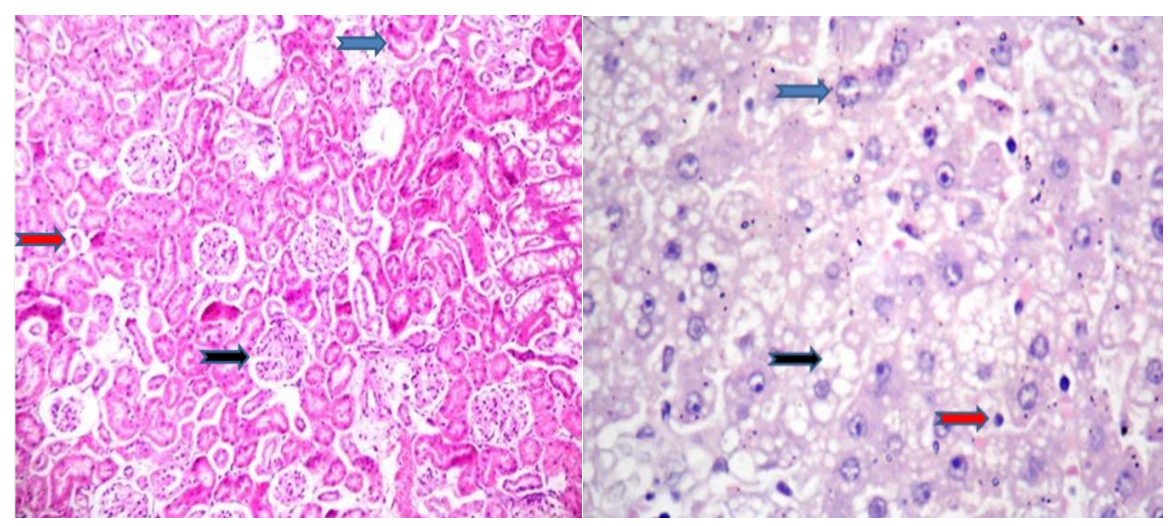

(a)

(b)

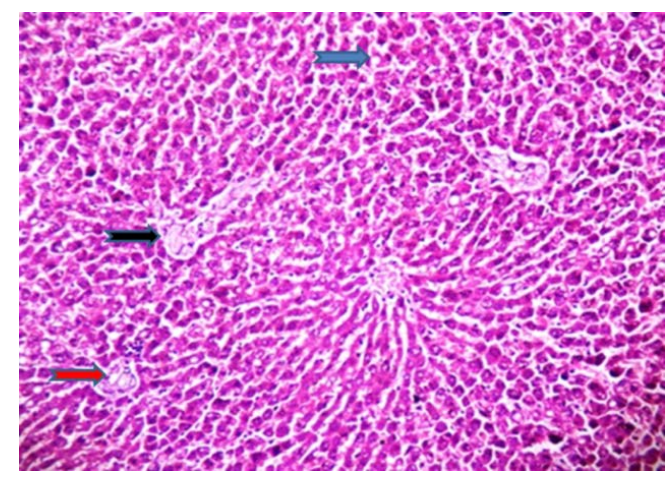

(c)

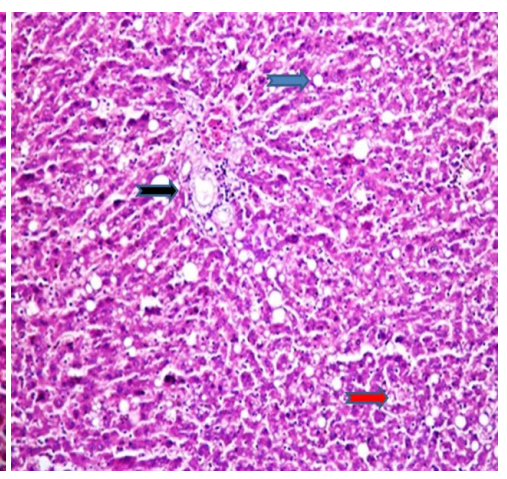

(d)

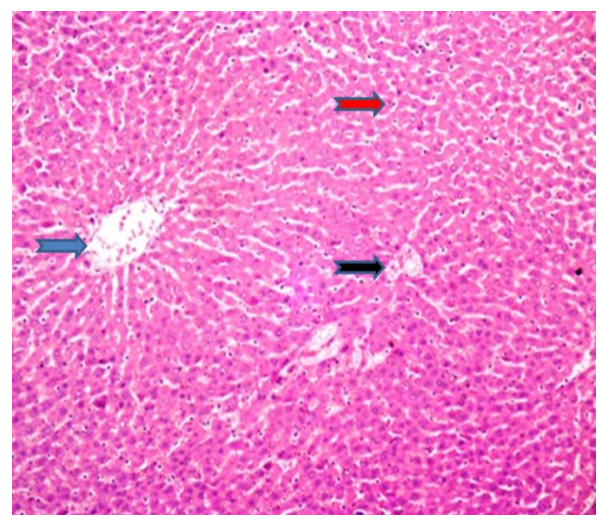

(e)

Figure 6. Histological Examination of Liver (photomicrographs) $(\times 400$ mag. $)(a)=$ LFCD, (b) $=\mathrm{HFCD},(\mathrm{c})=\mathrm{HFCD} / 3,(\mathrm{~d})=\mathrm{HFCD} / 6$, (e) $=\mathrm{HFCD} / 9$.

alkaloids, saponins, steroids, cardiac glycosides, tannins, flavonoids and volatile oil, while phlobatannins and terpenoids were not found. Studies have shown that the polyphenolic content in the plants are associated with their antioxidant activities and good potentials as anti-inflammatory, anti-diarrheal and anti-hemorrhoidal compound [32]. Hence, the presence of cardiac glycoside in Chrysophylum albidum makes it to be effective in congestive heart failure as reported by Aboaba et al. [33]. The presences of these metabolites confirm the usefulness of the plant in the treatment of various diseases [34]. The plant exhibited potent antioxidant activity. The presence of phenolic compound like tannins could be responsible for the free radical scavenging effect.

\subsection{Anitoxidant Activity of African Star Apple Juice}

The evaluation of phenol content and flavonoid content showed that African star apple juice is considerably rich 
Table 4. Summary of histopathology assay of organs from albino rats after 4 week consumption of African star apple juice experimental diets.

\begin{tabular}{ccc}
\hline Slides & Report \\
LFCD & Normal cardiac muscle \\
HFCD & Normal cardiac musclebundle, Normalcardiac myocyte, Thickened wall vascular channel \\
HFCD $/ 3$ & Normal cardiac artery, Normal cardiac myocyte \\
HFCD/9 & Normal cardiac vessel, Normal cardiac muscle bundle \\
HFCD & Normal cardiac muscle bundles \\
HFCD $/ 3$ & Normal renal tubule, Normal glomerulus, Normal renal vessel \\
HFCD/6 & Moderate fatty change, Portal triad with mild periportal inflammation, Degenerate hepatocytes \\
HFCD/9 & Central vein, Portal triad, Normal hepatocyte
\end{tabular}

LFCD = Low fat/cholesterol diet HFCD = High fat/cholesterol diet; HFCD/3 = High fat/cholesterol diet $+3 \mathrm{ml} \mathrm{African} \mathrm{star} \mathrm{apple} \mathrm{juice;} \mathrm{HFCD} / 6=$ High fat/cholesterol diet $+6 \mathrm{ml}$ African star apple juice; HFCD $/ 9=$ High fat $/$ cholesterol diet $+9 \mathrm{ml}$ African star apple juice; $\mathrm{L}=\mathrm{Liver}$; $\mathrm{H}=\mathrm{Heart}$ muscle.

Table 5. Phytochemical screening of the Juice of the fruit of Chrysophyllum albidum.

$\begin{array}{ccc}\text { Test } & \text { Juice } \\ \text { Steroids } & + \\ \text { Tannins } & + \\ \text { Alkaloids } & + \\ \text { Flavonoids } & + \\ \text { Cardiac glycoside } & + \\ \text { Phlobatannins } & + \\ \text { Saponins } & + \\ \text { Terpenoids } & + \\ \text { Volatile oil } & \end{array}$

(+) Present; (-) absent.

in phenol and flavonoids. Studies have shown phenol rich diets reduce oxidative DNA damage, Oxidative stress [35]. Hao et al. [36] found that Phenolic compounds are good electron donors and could terminate the radical chain reaction by converting free radical to more stable products.

The scavenging effect of phenolics (flavonoids) such as Quercetin has also been observed to significantly decrease water induced Reactive Oxygen Species elevation and has been recorded to inhibit oxidation modification of Low Density Lipoprotein and cytotoxicity of low density lipoprotein [37]. Flavonoids also inhibit cyclooxygenase, leading to lower platelet aggregation and reduced thrombotic tendencies [37].

African star apple juice showed a considerable content of total flavonoids which may possibly be responsible for the antioxidant activity coupled with the fact that phenolic and flavonoid compounds have been reported by Carew et al. [9] to be effective antioxidant constituents in plant foods including fruits, vegetables and grains [38]. These Cardio-protective actions of flavonoids, especially quercetin can be hypothesized to be manifested by African star apple juice.

Among the oxygen radicals, the hydroxyl radical is the most reactive which severely damages adjacent biomolecules such as Proteins, DNA, nucleic acid and almost any biological molecule it touches: this radical species is considered as one of the quick initiators of the lipid oxidation process, abstracting hydrogen atoms from unsaturated fatty acids [39]. Therefore, the removal of hydroxyl radical is probably one of the most effective 
defenses of a living body against various diseases.

The hydroxyl radical is an extremely reactive free radical formed in the biological systems and has been implicated as a highly damaging species in free radical pathology, capable of damaging almost every molecule found in living cells [40]. Scavenging of hydroxyl radicals is likewise an important antioxidant activity because of very high reactivity of the DPPH and $\mathrm{OH}^{-}$radicals which reduces its ability to react with a wide range of molecules found in living cells, such as amino acids, sugars, lipids and nucleotides [40].

The DPPH assay of African star apple juice validated its free radical scavenging activity. The scavenging ability was found to be concentration dependent.

\subsection{Serum Lipid Profile of Blood Obtained from Albino Rats after 4-Week Consumption of Experimental African Star Apple Juice Supplemented Diets}

The total blood cholesterol (TC), Triglycerides (TG), High Density lipoprotein Cholesterol (HDL-C) and Low Density Lipoprotein Cholesterol (LDL-C) values ranged from 109.81 - 215.67, 91.45 - 187.48, 20.10 - 46.40, and $45.12-158.07 \mathrm{mg} / \mathrm{dl}$ respectively. The values conform and are within the $<240 \mathrm{mg} / \mathrm{dl}$ (TC), $<200 \mathrm{mg} / \mathrm{dl}$ (TG), $\geq 10 \mathrm{mg} / \mathrm{dl}$ (HDL-C) and $<160 \mathrm{mg} / \mathrm{dl}$ (LDL-C) recommended for healthy individuals by the US guideline on health (mnuqol.com/blood-lipid-profile.htm); as such, none of the experimental animals have the tendency to develop hypercholesteromia and other serum-lipid induced/related health issues.

The oral administration of $1 \%$ cholesterol in High fat/cholesterol diet increased plasma total cholesterol, triglycerides, LDL, and VLDL to $215.67,187.48,158.07$, and $37.65 \mathrm{mg} / \mathrm{dl}$ respectively, as compared to the normal control. These significant rises were accompanied by a significant decrease in plasma HDL cholesterol to 20.10 $\mathrm{mg} / \mathrm{dl}$, as compared to the normal control (Table 3). The atherogenic index compared to the normal control was also increased significantly to 7.61 (Table 3 ). The oral supplementation of the extract of African star apple juice $(3 \mathrm{ml}, 6 \mathrm{ml}$, and $9 \mathrm{ml}$ ) to high cholesterol rats resulted in significant declines in plasma total cholesterol level to $182.77,165.90$ and $169.74 \mathrm{mg} / \mathrm{dl}$ respectively as compared to the high cholesterol fed rats $(215.67 \mathrm{mg} / \mathrm{dl})$. LDL, VLDL, and triglycerides also showed a significant decrease as compared to the high cholesterol fed rats to 117.21, 29.72, and 148.32 for $3 \mathrm{ml}$ African star apple juice extract, 113.87, 25.76, and 128.15 for $6 \mathrm{ml}$ African star apple juice extract and 105.85, 24.27 and 122.47 for $9 \mathrm{ml}$ African star apple juice (Table 3). Similarly atherogenic index was also reduced to about 4.09, 5.28 and 3.31 for African star apple juice extract $(3 \mathrm{ml}, 6 \mathrm{ml}, 9$ $\mathrm{ml}$ ) respectively (Table 3). It also elevated plasma HDL cholesterol to 35.9, 26.40 and 39.4 respectively.

In the human body, high levels of triglycerides in the bloodstream have been linked to atherosclerosis, and, by extension, the risk of heart disease and stroke. TG level was significantly decreased in the experimental groups (HFCD/3, HFCD/6, HFCD/9) compared to the treated control group (HFCD) $(\mathrm{P}>0.05)$. High cholesterol levels are strong indicators of those individuals that are prone to coronary heart disease. Elevated total cholesterol is a risk factor for coronary heart disease. The build-up of plaque in the artery may lead to narrowing (high blood pressure) or complete blockage (heart attack) of the vessel [41]. It is widely accepted that reduction in plasma HDL-C is a risk factor for developing atherosclerosis. HDL-C facilitates the translocation of cholesterol from the peripheral tissue, such as arterial walls to liver for catabolism. The increase in HDL-C may slow down the atherosclerotic process [42]. The results showed that the untreated control (LFCD) and African star apple juice supplemented-diets (HFCD/3, HFCD/6, HFCD/9) increased the concentrations of serum HDL-C when is compared with the cholesterol-rich diet (HFCD), and the concentrations of serum LDL-C too, were decreased.

Yeo and $\mathrm{Su}$ [43] reported that a statistically significant association occurs between elevated serum Total cholesterol and Low Density Lipoprotein Cholesterol (LDL-C) and the severity of Retinal hard exudation in patients with diabetic retinopathy. In the same study, [43] the researchers reported a literature support that oedema and hemorrhage may result from the incorporation of triglycerides into the cell membrane leading to changes in membrane fluidity and leakage of plasma constituents into the retina. Elevated levels of Triglyceride, Cholesterol and LDL-C are documented as risk factors for atherogenesis. LDL-C in its oxidized or acetylated form has been identified as a major atherogenic particle; as it not only load macrophages with cholesterol for the formation of foam cells but also because it is chemotactic for circulating monocytes, is cytotoxic and can adversely alter coagulation pathways [44]. The blood level of HDL-C in contrast bears an inverse relationship of the risk of atherosclerosis and coronary heart disease that is, higher the level, smaller the risk [45] [46]. Literature shows that correlations exist between Serum lipid profiles and sperm parameters. Vigrion et al. [47] found that increased triglyceride has deleterious effects on spermatogenesis. In like findings, Ergun et al. [22] investigated 
the correlations of semen parameters with lipid concentrations among 18 infertile men. Their results showed that increase of very Low Density Lipoprotein (LDL-C) and Triglyceride were significantly correlated with decreased sperm motion characteristics. Mohammad et al. [48] found out that triglyceride above normal level was related with abnormal sperm morphology and motility.

\subsection{Biochemical Analysis of Organs from Albino Rats after 4-Week Consumption of African Star Apple Juice Supplimented Diets}

The best cellular antioxidants are the enzymes superoxide dismutase (SOD), catalase (CAT), and glutathione peroxidase (GSH). Antioxidant enzymes such as SOD, reduced glutathione (GSH), catalase (CAT), play a vital role in protecting the cells from oxidative damage and are usually depleted during oxidative stress condition [49]. The scavenging activities observed against DPPH and hydroxyl radicals, as well as protective activities against lipid peroxidation, lead to proposing African star apple juice extract as a promising natural source of antioxidant suitable for application in nutritional/pharmacological fields, and in the prevention of free radical-mediated diseases.

Superoxide dismutase, (SOD) is a specific antioxidant enzyme which dismutates $\mathrm{O}_{2}^{-}$and forms $\mathrm{H}_{2} \mathrm{O}_{2}$ that is eventually scavenged by catalase or glutathione peroxidase [50] [51]. These enzymes prevent generation of hydroxyl radical and protect the cellular constituents from oxidative damage [52]. The significant decrease ( $<<$ 0.05) in activities of SOD in High Fat/Cholesterol Diet (HFCD) treated rats might be due to increase production of the superoxide anion radical and the channeling of the antioxidant enzymes towards its removal [16]. Hence, the observed inhibition of HFCD effect in African star apple juice $(3,6$, and $9 \mathrm{ml})$ treated rats Figure 2 suggested that African star apple juice at those dosage were capable of either attenuating HFCD-induced superoxide anion $\left(\mathrm{O}_{2}^{-}\right)$production or boosting cardiac cells SOD production capacity.

Catalase, the perixosomal antioxidant enzyme, is frequently used by cells to rapidly catalyze the decomposition of hydrogen peroxide into less reactive gaseous oxygen and water molecules [53]. Hydrogen peroxide is a harmful by-product of many normal metabolic processes, and to prevent damage, it must be quickly converted into other, less dangerous substances. The significant decrease in catalase activity of HFCD-treated rats lends support to the claim that $\mathrm{H}_{2} \mathrm{O}_{2}$ is one of the products of HFCD metabolism [54]. African star apple juice (3, 6, and $9 \mathrm{ml}$ ) treatment therefore proved protective by reversing the HFCD decrease in the antioxidant enzyme level.

The endogenous antioxidant molecule, glutathione (GSH), can interact directly with certain ROS (like hydroxyl radical) to detoxify them, as well as performing other critical activities in the cell [49]. The level of GSH, which comprises in most instances the bulk of cellular non-protein sulfhydryl groups, is a measure of cellular redox status [55], and is usually depleted during oxidative stress conditions [49].

GSH is also an essential component of the glutathione peroxidase system where the selenium-containing microsomal enzyme, GPx, catalyses the degradation of hydrogen peroxide to water and reduces organic peroxides to alcohols, providing another route for eliminating toxic oxidants.

The observed depletion in GSH levels in HFCD-treated rat is in line with previous reports [56], further confirming the lipid peroxidation caused by HFCD. Hence the observed inhibition of HFCD depletion in African star apple juice lends support to the protective antioxidant benefit of the intervention.

Malonaldehyde (MDA) is one of the degradative products of free radical-mediated oxidation of polyunsaturated fatty acids (PUFA) in biological membranes [46]. The production of this aldehyde is used as a biomarker to measure the level of oxidative stress in an organism since lipid peroxidation is directly related to oxidative damage [57]. The $\mathrm{H}_{2} \mathrm{O}_{2}$ resulting from African star apple juice metabolism can be converted to highly toxic hydroxyl radicals $\left(\mathrm{OH}^{-}\right)$in the presence of transition metal, most often $\mathrm{Fe}^{2+}[58]$. These ROS are toxic and react with lipids, proteins and nucleic acids, resulting in lipid peroxidation, depletion of sulfhydryl-containing peptides (glutathione inclusive), and damage to DNA. Hence, the observed inhibition of HFCD MDA elevation in ASAJ supported the protective antioxidant benefit of ASAJ.

\subsection{Histological Assay of Organs from Albino Rats after 4-Week Consumption of African Star Apple Juice Treated Experimental High Fat/Cholesterol Diets}

The histological assays of hearts and livers from albino rats after 28 days consumption of experimental High fat/cholesterol diet are shown in Figure 5. The figure showed that there were no inflammatory or degenerative 
conditions seen in the histological structure of organs (heart and liver) excised from the animals that fed on low fat/cholesterol diet. This may be due to the fact that the diet did not contain toxic polycyclic aromatic hydrocarbons (PAHs) and dioxin (Polychlorinated dibenzo-p-dioxin and polychlorodibenzo furans) a family of polychlorinated tricyclic aromatic compounds which are documented for their mutagenic or carcinogenic potential [59]. The result obtained during the heart histology also showed that the fat in the diet are not thermal stressed and so cytotoxic aldehyde product which could promote the induction, development and progression of CVD are not generated [60].

From the summary of the histopathology of the heart and liver obtained from the animals that fed on High fat/cholesterol diet, the heart maintained normal cardiac muscle bundle and normal cardiac myocytes but with thickened wall vascular channel which is an evidence of severe degeneration of vascular wall. In the liver, there is a very severe degeneration of hepatocytes and hepatic necrosis (cell death). The occurrence of hepatocytes necrosis as induced by the consumption of High Fat/Cholesterol Diet is evidence of hepatitis [61]. This evidence showed that the High Fat/Cholesterol Diet possessed some chemical and pharmacological properties similar to the classes of drugs that are capable of inducing liver damage and this explains their capability to effect the histological changes observed.

Figure 5 and Figure 6 show the histology of the heart and liver obtained from $3 \mathrm{ml} \mathrm{ASAJ}$ treated animals that fed on High Fat/Cholesterol Diet. This histology showed the heart does not have any visible lesion. There were no inflammatory or degenerative conditions seen in the heart. This may be attributed to lipid lowering effects of ASAJ. Also ASAJ contains polyphenols which are characterized as having antioxidative and anti-inflammatory capacities. The liver showed normal portal triad but slightly distended sinusoid. This showed that the location for the oxygen rich blood from the hepatic artery and the nutrient rich blood from the portal vein has been affected [62]. The distended sinusoid seen in the liver of $3 \mathrm{ml}$ ASAJ treated animals fed on High Fat/Cholesterol Diet may be due to dosage dependence.

The histopathology of the heart and liver of the $6 \mathrm{ml}$ ASAJ treated animals fed on High Fat/Cholesterol Diet are clearly designated. The histology showed that the heart does not have any visible lesion. ASAJ treatment therefore had a protective effect against myocardial infarction. The liver showed degeneration of hepatocytes with mild periportal inflammation of the portal triad. The protective capacity of the ASAJ against liver degeneration could be attributed to dosage dependence.

Figure 5 and Figure 6 also show the histology of the heart and liver of $9 \mathrm{ml}$ ASAJ treated animals fed with High Fat/Cholesterol Diet. Both the heart and the liver obtained did not show any visible lesion and there were no inflammatory or degenerative conditions seen in these organs. This may be attributed to serum antioxidant capacity of African Star Apple juice on a High Fat/Cholesterol Diet. This study has aligned with previous reports [63] [64] that the solution to most human nutritional and health problems lies in the exploitation of underutilized and lesser-known wild forest seeds.

\section{Conclusion}

The present study demonstrated that diet-induced hypocholesterolemic atherosclerosis was associated with an increase in the oxidative stress and that African star apple juice reduced the extent of atherosclerosis by reducing oxidative stress and serum TC, TG, LDL-C and raising serum HDL-C. Also, treatment with the African star apple juice offered protection against high fat/cholesterol diet-induced damage to the cardiac tissues possibly through positive modulation of the cardiac antioxidant system. African star apple juice is a promising supplement for improving defence mechanisms in the body system against oxidative stress. The findings therefore support the ethno medicinal uses of the juice in the management of cardiovascular complications like atherosclerosis and hypertension.

\section{References}

[1] Bada, S.O. (1997) Preliminary Information on the Ecology of Chrysophillum albidum G. Don, in West and Central Africa. Proceedings of a National Workshop on the Potentials of the Star Apple in Nigeria, Ibadan, November 1997, 16-25.

[2] Adewusi, H.A. (1997) The African Star Apple, Chrysophyllum albidum Indigenous Knowledge from Ibadan, Southwestern Nigeria. Proceedings of a National Workshop on the Potentials of the Star Apple in Nigeria, Ibadan, November $1997,25-33$. 
[3] Cenrad (1999) Centre for Environmental Renewable Natural Resources Management, Research and Development. Jericho, Ibadan.

[4] Akubugwo, I.E. and Ugbogu, A.E. (2007) Physicochemical Studies on Oils from Five Selected Nigerian Plant Seeds. Pakistan Journal of Nutrition, 6, 75-78. http://dx.doi.org/10.3923/pin.2007.75.78

[5] Inkeles, S. and Eisenberg, D. (1981) Hyperlipidemia and Coronary Atherosclerosis: A Review. Medicine, 60, $110-123$. http://dx.doi.org/10.1097/00005792-198103000-00004

[6] Tunstall, P.H. and Smith, W.C. (1990) Cholesterol as a Risk Factor for Coronary Heart Disease. British Medical Bulletin, 46, 1075-1087.

[7] Anderson, J.W. and Hana, T.J. (1999) Impact of Nondigestiable Carbohydrates on Serum Lipoproteins and Risk for Cardiovascular Disease. Journal of Nutrition, 129, 1457-1466.

[8] Witzum, J.L. and Steinberg, D. (2001) The Oxidative Modification Hypothesis of Atherosclerosis: Does It Hold for Humans? Trends in Cardiovascular Medicine, 1, 93-102. http://dx.doi.org/10.1016/S1050-1738(01)00111-6

[9] Carew, T.E., Schwence, D.C. and Steinberg, D. (1987) Antiatherogenic Effect of Probucol Unrelated to Its Hypocholesterolemic Effect: Evidence That Antioxidants In Vivo Can Selectively Inhibit Low Density Lipoprotein Degradation in Macrophage-Rich Fatty Streaks and Slow the Progression of Atherosclerosis in the Watanabe Heritable Hyperlipidemic Rabbit. Proceedings of the National Academy of Sciences of the United States of America, 84, 7725-7729. http://dx.doi.org/10.1073/pnas.84.21.7725

[10] Okoli, B.J. and Okere, O.S. (2010) Antimicrobial Activity of the Phytochemical Constituents of Chrysophylum Albidum G. Don Holl. (African Star Apple) Plant. Journal of Research in National Development, 8, 1-22.

[11] Sofowora, A. (1993) Medicinal Plants and Traditional Medicine in Africa. Spectrum Books Ltd., Ibadan.

[12] Wall, M.E., Krider, M.M., Krewson, C.F., Eddy, C.R., Wilaman, J.J., Correll, S. and Gentry, H.S. (1954) Steroidal Sapogenins XII. Supplementary Table of Data for Steroidal Sapogenins VII. Agricultural Research Service, $363,17$.

[13] Trease, E.G. and Evans, W.C. (1978) Pharmacognosy. 11th Edition, Balliere Tindall, London, 115-222.

[14] Edeoga, H.O., Okwu, D.E. and Mbaebie, B.O. (2005) Phytochemical Constituents of Some Nigerian Medicinal Plants. African Journal of Biotechnology, 4, 685-688. http://dx.doi.org/10.5897/AJB2005.000-3127

[15] Benderitter, M., Maupoil, V., Vergely, C., Dalloz, F., Briot F. and Rochette, L. (1998) Studies by Electron Paramagnetic Resonance of the Importance of Iron in the Hydroxyl Scavenging Properties of Ascorbicacid in Plasma: Effects of Iron Chelators. Fundamental and Clinical Pharmacology, 12, 510-516. http://dx.doi.org/10.1111/j.1472-8206.1998.tb00979.x

[16] Singleton, V.L., Orthofor, R. and Lamuela-Raventos, R.M. (1999) Analysis of Total Phenols and Other Oxidation Substrates and Antioxidants by Means of Folin-Ciocaltau Reagent. Methods in Enzymology, 299, 152-178. http://dx.doi.org/10.1016/S0076-6879(99)99017-1

[17] Meda, A., Lamien, C.E., Romito, M., Millogo, J. and Nacoulma, O.G. (2005) Determination of the Total Phenolic, Flavonoid and Proline Contents in Burkina Faso Honey, as Well as Their Radical Scavenging Activity. Food Chemistry, 91, 571-577. http://dx.doi.org/10.1016/j.foodchem.2004.10.006

[18] Gyamfi, M.A., Yonamine, M. and Aniya, Y. (1999) Free Radical Scavenging Action of Medicinal Herbs from Ghana: Thonningia Sanguinea on Experimentally Induced Liver Injuries. General Pharmacology, 32, 661-667. http://dx.doi.org/10.1016/S0306-3623(98)00238-9

[19] Oyaizu, M. (1986) Studies on Products of Browning Reaction Prepared from Glucoseamine. Japanese Journal of Nutrition, 44, 307-314. http://dx.doi.org/10.5264/eiyogakuzashi.44.307

[20] Minotti, G. and Aust, S.D. (1987) An Investigation into the Mechanism of Citrate-Fe ${ }^{2+}$-Dependent Lipid Peroxidation. Free Radical Biology \& Medicine, 3, 379-387. http://dx.doi.org/10.1016/0891-5849(87)90016-5

[21] Puntel, R.L, Nogueira, C.W. and Rocha, J.B.T. (2005) Krebs Cycle Intermediates Modulate Thiobarbituric Reactive Species (TBARS) Production in Rat Brain In Vitro. Neurochemical Research, 30, 225-235. http://dx.doi.org/10.1007/s11064-004-2445-7

[22] Erqun, A., Kose, S.K., Aydos, K., Ata, A. and Avci, A. (2007) Correlation of Seminal Parameters with Serum Lipid Profile and Sex Hormones. Archives of Andrology, 53, 21-23. http://dx.doi.org/10.1080/01485010600888961

[23] Friedewald, W.T., Levy, R.I. and Fredickson, D.S. (1972) Estimation of Concentration Oflow-Density Lipoprotein Cholesterol in Plasma without Use of the Preparative Ultracentrifuge. Clinical Chemistry, 18, 499-502.

[24] Sinha, A.K. (1972) Colorimetric Assay of Catalase. Analytical Biochemistry, 47, 389-394. http://dx.doi.org/10.1016/0003-2697(72)90132-7

[25] Misra, H.P. and Fridovich, I. (1972) The Role of Superoxide Anion in the Autoxidation of Epinephrine and a Sample Assay for Superoxide Dismutase. The Journal of Biological Chemistry, 247, 3170-3175. 
[26] Beutler, E., Duron, O. and B. Kelly, M. (1963) Improved Method for the Determination of Improved Method for the Determination of Blood Glutathione. Journal of Laboratory and Clinical Medicine, 61, 882-888.

[27] Varshney, R. and Kale, R.K. (1990) Effects of Calmodulin Antagonists on Radiation-Induced Lipid Peroxidation in Microsomes. International Journal of Radiation Biology, 58, 733-43. http://dx.doi.org/10.1080/09553009014552121

[28] Adam Vizi, V. and Seregi, M. (1982) Receptor Dependent Stimulatory Effect of Noradrenaline on $\mathrm{Na}^{+} / \mathrm{K}^{+} \mathrm{ATPase}$ in Rat Brain Homogenate. Role of Lipid Peroxidation. Biochemical Pharmacology, 31, 2231-2236. http://dx.doi.org/10.1016/0006-2952(82)90106-X

[29] Bancroft, J.D. and Steven, A. (1990) Theory \& Practice of Histological Technique. 3rd Edition, Churdchill Livingstone, New York.

[30] Topping, D.L., Trimble, R.P., Illman, R.J., Potter, J.D. and Oakenfull, D.G. (1980) Prevention of Dietary Hypercholesterolemia in the Rat by Soy Flour High and Low in Saponins. Nutrition Reports International, 22, 513-519.

[31] Asquith, T.N. and Butler, L.G. (1986) Interactions of Condensed Tannins with Selected Proteins. Phytochemistry, 25, 1591-1593. http://dx.doi.org/10.1016/S0031-9422(00)81214-5

[32] Kamba, A.S. and Hassan, L.G. (2011) Phytochemical Screening and Antimicrobial Activities of African Star Apple (Chrysophyllum albidum) Leaves, Stem against Some Pathogenic Microorganism. International Journal of Pharmaceutical Frontier Research, 1, 119-129.

[33] Aboaba, O.O., Smith, S.T. and Olide, F.O. (2006) Antimicrobial Effect of Edible Plant Extract on Escherichia coli 0157: H7. Pakistan Journal of Nutrition, 5, 325-327. http://dx.doi.org/10.3923/pjn.2006.325.327

[34] Chang, S.T., Wu, J.H., Wang, S.Y., Kang, P.L., Yang, N.S. and Shyur, L.F. (2001) Antioxidant Activity of Extract from Acacia Confuse Bark and Heart Wood. Journal of Agricultural and Food Chemistry, 49, 3420-3424. http://dx.doi.org/10.1021/jf0100907

[35] Lim, K.L., Kolatkar, P.R., Ng, K.P., Ng, C.H. and Pallen, C.J. (1998) Interconversion of the Kinetic Identities of the Tandem Catalytic Domains of Receptor-Like Protein-Tyrosine Phosphate PTP $\alpha$ by Two Point Mutations Is Synergistic and Substrate-Dependent. The Journal of Biological Chemistry, 273, 28986-28993. http://dx.doi.org/10.1074/jbc.273.44.28986

[36] Hao, Z.L., Zhang, X.M. and Zhang, P.D. (2007) Biological Characteristics and Multiplication Techniques of Sepia Esculenta. Chinese Journal of Ecology, 26, 601-606.

[37] Rao, T.S., Lariosa, K., Lin, F.-F., Palfreyman, E.L., Yu, N., Chun, J. and Webb, M. (2003) Pharmacological Characterization of Lysophospholipid Receptor Signal Transduction Pathways in Rat Cerebrocortical Astrocytes. Brain Research, 990, 182-194. http://dx.doi.org/10.1016/S0006-8993(03)03527-3

[38] Imaga, N.O.A., Gbenle, G.O., Okochi, V.I., Akanbi, S.O., Edeoghon, S.O., Oigbochie, V., Kehinde, M.O. and Bamiro, S.B. (2009) Antisickling Property of Carica Papaya Leaf Extract. African Journal of Biochemistry Research, 3, 102106.

[39] Aruoma, O.I. (1998) Free Radicals, Oxidative Stress, and Antioxidants in Human Health and Disease. Journal of the American Oil Chemists' Society, 75, 199-212. http://dx.doi.org/10.1007/s11746-998-0032-9

[40] Yasuda, T., Inaba, A., Ohmori, M., Endo, T., Kubo, S. and Ohsawa, K. (2000) Urinary Metabolites of Gallic Acid in Rats and Their Radical Scavenging Effect on DPPH. Journal of Natural Products, 63, 1444-1446. http://dx.doi.org/10.1021/np0000421

[41] Karantonis, H.C., Antonopoulou, S., Perrea, D.N., Sokolis, D.P., Theocharis, S.E. and Kavantzas, N. (2006) In Vivo Antiatherogenic Properties of Olive Oil and Its Constituents Lipid Classic in Hyperlipidemic Rabbits. Nutrition, Metabolism and Cardiovascular Diseases, 16, 174-185. http://dx.doi.org/10.1016/j.numecd.2005.07.003

[42] Nofer, J.R., Kehrel, B., Fobker, M., Levkau, B., Assmann, G. and von Eckardstein, A. (2002) HDL and Arteriosclerosis: Beyond Reverse Cholesterol Transport. Atherosclerosis, 161, 1-16. http://dx.doi.org/10.1016/S0021-9150(01)00651-7

[43] Yeo, K.T. and Su, D.H.W. (2000) Diabetic Retinopathy and Serum Lipids. Singapore Medical Journal, 41, $295-297$.

[44] Abubakar, A., Mabruok, M.A., Gerie, A.B., Dikko, A.A., Aliyu, S., Yusuf, T., Magaji, R.A., Kabir, M.A. and Adama, U.W. (2009) Relation of Body Mass Index with Lipid Profile and Blood Pressure in Healthy Female of Lower Socioeconomic Group, in Kaduna Northern Nigeria. Asian Journal of Medical Sciences, 1, 94-96.

[45] Witztum, J.L. and Stemberg, D. (1991) Role of Oxidized Low Density Lipoprotein in Atherogenesis. Journal of Clinical Investigation, 88, 1785-1792. http://dx.doi.org/10.1172/JCI115499

[46] Pryor, W.A. and Stanley, J.P. (1975) A Suggested Mechanism for the Production Ofmalonaldehyde during the Autoxtdatton of Polyunsaturated Fatty Acids. Nonenzymatic Production Ofprostaglandin Endoperoxides during Autoxtdation. Journal of Organic Chemistry, 40, 3615-3617. http://dx.doi.org/10.1021/jo00912a038

[47] Vignon, F., Koll-Back, M.H., Clarert, A. and Cranz, L. (1989) Lipid Composition of Human Seminal Plasma. Archives 
of Andrology, 22, 49-53. http://dx.doi.org/10.3109/01485018908986750

[48] Mohammad, A.K., Najineh, Z. and Hamideh, H. (2009) Correlation between Serum Lipids Profile with Sperm Parameters of Infertile Men with Abnormal Semen-Analysis. Iranian Journal of Reproductive Medicine, 7, 123-127.

[49] Aldridge, W.N. (1981) Mechanism of Toxicity: New Concepts Are Required In Toxicology. Trends in Pharmacological Science, 2, 228-231. http://dx.doi.org/10.1016/0165-6147(81)90321-7

[50] Irmak, M.K., Fadillioglu, E., Gulec, M., Eedogan, H., Yagmurca, M. and Akyoi, O. (2002) Effects of Electromagnetic Radiation from a Cellular Telephone on the Oxidant and Antioxidant Levels in Rabbits. Cell Biochemistry and Function, 20, 279-283. http://dx.doi.org/10.1002/cbf.976

[51] Ilhan, A., Gurei, A., Armutcu, F., Kamisli, S., Iraz, M., Akoyi, O. and Ozen, S. (2004) Ginkgo Bilobe Prevents Mobile Phone-Induced Oxidative Stress in Rats Brain. Clinica Chimica Acta, 340, 153-162. http://dx.doi.org/10.1016/j.cccn.2003.10.012

[52] Scott, M.D., Lubin, B.H. and Kuypers, F.A. (1991) Erythrocyte Defence against Hydrogen Peroxide. Preeminent Importance of Catalase. Journal of Laboratory and Clinical Medicine, 118, 7-16.

[53] Gaetani, G., Ferraris, A., Rolfo, M., Mangerini, R., Arena, S. and Kirkman, H. (1996) Predominant Role of Catalase in the Disposal of Hydrogen Peroxide within Human Erythrocytes. Blood, 87, 1595-1599.

[54] Karim, S., Bhandari, U., Kumar, H., Salam, A., Siddiqui, M.A,A. and Pillai, K.K (2001) Doxorubicin Induced Cardiotoxicity and Its Modulation by Drugs. Indian Journal of Pharmacology, 33, 203-207.

[55] Chance, B., Sies, H. and Boveris, A. (1979) Hydroperoxide Metabolism in Mammalian Organs. Physiological Research, 59, 527-605.

[56] Doroshow, J.H. (1991) Doxorubicin-Induced Cardiotoxicity. The New England Journal of Medicine, 324, 843-845. http://dx.doi.org/10.1056/NEJM199103213241210

[57] Viani, P., Cervato, G., Fiorilli, A. and Cestaro, B. (1991) Age Related Difference in Sypnatozomal Peroxidative Damage and Membrane Properties. Journal of Neurochemistry, 56, 253-258. http://dx.doi.org/10.1111/j.1471-4159.1991.tb02589.x

[58] Halliwell, B. (1994) Free Radicals, Antioxidants and Human Disease: Curiosity, Cause or Consequence. The Lancet, 344, 721-724. http://dx.doi.org/10.1016/S0140-6736(94)92211-X

[59] Shastry, C.S., Patel Narendrakumar, A., Joshi, H. and Aswathanarayana, B.J. (2011) Evaluation of Effect of Reused Edible Oils on Vital Organs of Wister Rats. Nitte University Journal of Health Science, 1, 10-15.

[60] Quiles, J.L., Huertas, J.R., Battino, M., Tortosa, M.C., Cassinello, M. and Mataix, J. (2002) The Intake of Fried Virgin Olive or Sunflower Oils Differentially Induces Oxidative Stress in Rat Liver Microsomes. British Journal of Nutrition, 88, 57-65. http://dx.doi.org/10.1079/BJN2002588

[61] Nwaopara, A.O., Odike, M.A.C., Igegbenebor, U. and Adeoye, M.I. (2007) The Combined Effects of Excessive Consumption of Ginger, Clove, Red Pepper and Black Pepper on the Histology of Liver. Pakistan Journal of Nutrition, 6 , 524-527. http://dx.doi.org/10.3923/pjn.2007.524.527

[62] Sellaro, T.L., Ravindra, A.K., Stolz, D.B. and Badylak, S.F. (2007) Maintenance of Hepatic Sinusoidal Endothelial Cell Phenotype In Vitro Using Organ-Specific Extracellular Matrix Scaffolds. Tissue Engineering, 13, 2301-2310. http://dx.doi.org/10.1089/ten.2006.0437

[63] Enujiugha, V.N. and Ayodele-Oni, O. (2003) Evaluation of Nutrients and Some Anti-Nutrients in Lesser-Known Underutilized Oilseeds. International Journal of Food Science and Technology, 38, 525-528. http://dx.doi.org/10.1046/j.1365-2621.2003.00698.x

[64] Enujiugha, V.N. (2005) Quality Dynamics in the Processing of Underutilized Legumes and Oilseeds. In: Dris, R., Ed., Crops: Growth, Quality and Biotechnology, WFL Publisher, Helsinki, 732-746. 


\section{Submit or recommend next manuscript to SCIRP and we will provide best service for you:}

Accepting pre-submission inquiries through Email, Facebook, LinkedIn, Twitter, etc.

A wide selection of journals (inclusive of 9 subjects, more than 200 journals)

Providing 24-hour high-quality service

User-friendly online submission system

Fair and swift peer-review system

Efficient typesetting and proofreading procedure

Display of the result of downloads and visits, as well as the number of cited articles

Maximum dissemination of your research work

Submit your manuscript at: http://papersubmission.scirp.org/ 